\title{
Oxidation of hydrogen peroxide by $\left[\mathrm{Ni}^{\mathrm{III}}(\text { cyclam })\right]^{3+}$ in aqueous acidic media
}

\author{
SANKARAN ANURADHA and VENKATAPURAM RAMANUJAM VIJAYARAGHAVAN* \\ Department of Physical Chemistry, University of Madras, Guindy Campus, Chennai 600 025, India \\ e-mail: smradha73@gmail.com; viju47@yahoo.co.in
}

MS received 29 August 2012; revised 9 February 2013; accepted 8 March 2013

\begin{abstract}
The kinetics of oxidation of $\mathrm{H}_{2} \mathrm{O}_{2}$ by $\left[\mathrm{Ni}^{\mathrm{III}}(\text { cyclam })\right]^{3+},\left[\mathrm{Ni}^{\mathrm{III}} \mathrm{L}_{1}\right]$, was studied in aqueous acidic media at $25^{\circ} \mathrm{C}$ and $\mathrm{I}=0.5 \mathrm{M}\left(\mathrm{NaClO}_{4}\right)$. The $\left[\mathrm{Ni}^{\mathrm{III}} \mathrm{L}_{1}\right]$ to $\left[\mathrm{Ni}^{\mathrm{II}} \mathrm{L}_{1}\right]$ reduction was found to be fast in the presence of $\mathrm{Cu}(\mathrm{II})$ ion than the oxidation of the cyclam ligand by ${ }^{\circ} \mathrm{OH}$. The rate constant showed an inverse acid dependence on $\mathrm{H}^{+}$ion at the $\mathrm{pH}$ range 1-1.5. The presence of sulphate retards the reaction. Macrocylic ligand oxidation was followed spectrophotometrically by examining the oxidation of nickel(II) complexes of macrocyclic ligands such as 1,8-bis(2-hydroxyethyl)-1,3,6,8,10,13-hexaazacyclotetradecane $\left(\mathrm{L}_{2}\right), m s-5,7,7,12,14,14$ hexamethyl-1,4,8,11-tetraazacyclotetradecane $\left(\mathrm{L}_{3}\right)$, rac- $\mathrm{Me}_{6}[14]-4,11$-dieneN $\mathrm{N}_{4}\left(\mathrm{~L}_{4}\right)$ by reaction with hydrogen peroxide. The rate constant for the cross reaction is discussed in terms of Marcus relationship.
\end{abstract}

Keywords. Nickel(III) cyclam; hydrogen peroxide oxidation; $\mathrm{Cu}(\mathrm{II})$ catalyst.

\section{Introduction}

Extensive reports are available in literature on the metal ion-catalysed decomposition of hydrogen peroxide. It has been suggested that the equilibria for the complex formation between hydrogen peroxide and the aqua-cations $\mathrm{Fe}^{\mathrm{III}}(\mathrm{aq}),{ }^{1-3} \mathrm{Ce}^{\mathrm{IV}}(\mathrm{aq}),{ }^{4,5} \mathrm{Mn}^{\mathrm{III}}(\mathrm{aq}),{ }^{4,6}$ $\mathrm{Co}^{\mathrm{III}}(\mathrm{aq}),{ }^{4,7,8}$ and $\mathrm{Ag}^{\mathrm{II}}(\mathrm{aq})^{4,9}$ are established more rapidly than the rate of decomposition of hydrogen peroxide. The kinetic study of the complex formation between iron(III)-EDTA with hydrogen peroxide in aqueous solution was carried out in alkaline medium. ${ }^{10}$ At higher acidity $\left(\left[\mathrm{H}^{+}\right]>0.5 \mathrm{~mol} \mathrm{dm}{ }^{-3}\right)$, the kinetics of oxidation of hydrogen peroxide by $\left[\mathrm{Ni}(\text { bipy })_{3}\right]^{3+}$ was found to be independent of $\left[\mathrm{H}^{+}\right]$and no replacement of the ligand on the nickel(III) centre by $\mathrm{H}_{2} \mathrm{O}_{2}$ was observed. ${ }^{11}$ Oxidation of hydrogen peroxide by tris(2,2'-bipyridine) and tris(4,4'-dimethyl-2,2'bipyridine) complexes of osmium(III), iron(III), ruthenium(III), and nickel(III) studied in acidic and neutral aqueous media, show an inverse acid dependence over the $\mathrm{pH}$ the range 6.0-8.5. ${ }^{12}$ Kinetic measurements with an excess of $\mathrm{H}_{2} \mathrm{O}_{2}$ revealed that $\mathrm{HO}_{2}^{-}$ is the only redox-active species for the reaction with $\left[\mathrm{Ni}(\operatorname{tacn})_{2}\right]^{3+}$ under conditions $2<\mathrm{pH}<5.5$, while the

*For correspondence participation of both $\mathrm{H}_{2} \mathrm{O}_{2}$ and $\mathrm{HO}_{2}^{-}$was observed for the reactions with $\left[\mathrm{Fe}(\mathrm{ttcn})_{2}\right]^{3+}$ and $\left[\mathrm{Ru}(\text { bipy })_{3}\right]^{3+}$. The reaction pathway for the oxidation of hydrogen peroxide in acidic solution by $\left[\mathrm{Ni}(\operatorname{tacn})_{2}\right]^{3+}$ involves interaction of $\mathrm{HO}_{2}^{-}$with the amino hydrogen atom on the tacn ligand. ${ }^{13}$

An attempt for reduction of $\left[\mathrm{Ni}^{\mathrm{III}} \mathrm{L}_{1}\right]$ centre by $\mathrm{H}_{2} \mathrm{O}_{2}$ revealed that it was slow and complicated by the ligand oxidation. Reaction of $\left[\mathrm{NiL}_{1}\right]^{2+}$ with hydrogen peroxide in acidic media results in the formation of a dimeric complex in which there is an evidence for electron delocalization across the $\mathrm{M}-\mathrm{M}$ distance. ${ }^{14}$ Laurence et al., studied that the nickel(III) complexes of the ligands $\left(\mathrm{L}_{3}\right.$ and $\left.\mathrm{L}_{4}\right)$ which contain $\mathrm{NH}$ groups are converted into nickel(II) complexes of radical forms of the ligands at $\mathrm{pH}>3 .{ }^{15}$ The pulse radiolysis study suggested that the hydroxyl radicals oxidize the nickel(II) complexes by initial H-atom abstraction from the ligand, and the nickel(III) complexes are then formed by proton-assisted intramolecular electron transfer. Homolytic O-O cleavage for the reaction of $\left[\mathrm{Ni}^{\mathrm{II}}\right.$ cyclam $\left.\left(\mathrm{CH}_{3} \mathrm{CN}\right)_{2}\right]\left(\mathrm{ClO}_{4}\right)_{2}$ with TBHP (tert-Butyl hydroperoxide) in $\mathrm{CH}_{3} \mathrm{CN}$ and proton assisted heterolysis for $\mathrm{O}-\mathrm{O}$ activation in $\mathrm{H}_{2} \mathrm{O}$ was studied. ${ }^{16}$ In this paper, we report kinetics of $\mathrm{Cu}(\mathrm{II})$ catalysed oxidation of hydrogen peroxide by $\left[\mathrm{Ni}^{\mathrm{III}} \mathrm{L}_{1}\right]$. Nickel(II) complexes of macrocyclic ligands in scheme 1 were examined towards ligand oxidation by carrying out oxidation of metal centre by hydrogen peroxide and $t$-Butyl hydroperoxide. 


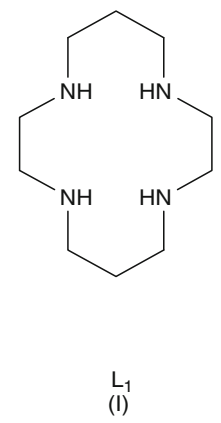

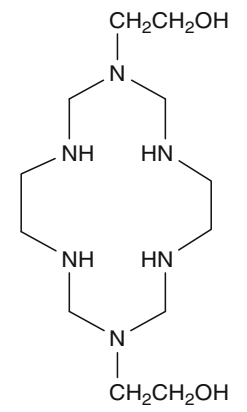

$\mathrm{L}_{2}$

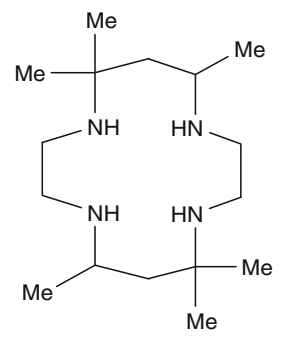

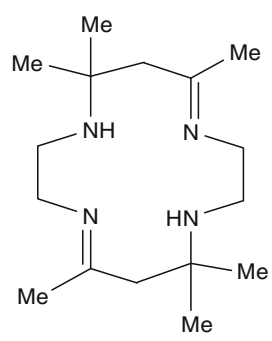

(IV)

Scheme 1. Structure of macrocyclic ligands.

\section{Experimental}

\subsection{Materials and reagents}

$\left[\mathrm{NiL}_{1}\right]\left(\mathrm{ClO}_{4}\right)_{2}$, and the corresponding $\left[\mathrm{NiL}_{1}\left(\mathrm{NO}_{3}\right)_{2}\right] \mathrm{ClO}_{4}$ complexes were prepared as described previously. ${ }^{17,18}\left[\mathrm{NiL}_{2}\right]\left(\mathrm{ClO}_{4}\right)_{2}\left(\varepsilon_{444}=54 \mathrm{M}^{-1} \mathrm{~cm}^{-1}, \varepsilon_{205}=\right.$ $\left.15,300 \mathrm{M}^{-1} \mathrm{~cm}^{-1}\right),\left[\mathrm{NiL}_{3}\right]\left(\mathrm{ClO}_{4}\right)_{2}\left(\varepsilon_{437}=100 \mathrm{M}^{-1}\right.$ $\mathrm{cm}^{-1}, \varepsilon_{282}=7,140 \mathrm{M}^{-1} \mathrm{~cm}^{-1}, \varepsilon_{215}=22,000 \mathrm{M}^{-1}$ $\left.\mathrm{cm}^{-1}\right)$, and $\left[\mathrm{NiL}_{4}\right]\left(\mathrm{ClO}_{4}\right)_{2} \quad\left(\varepsilon_{463}=68 \mathrm{M}^{-1} \mathrm{~cm}^{-1}\right.$, $\left.\varepsilon_{236}=12,900 \mathrm{M}^{-1} \quad \mathrm{~cm}^{-1}, \quad \varepsilon_{207}=8,660 \mathrm{M}^{-1} \quad \mathrm{~cm}^{-1}\right)$ complexes have also been prepared and characterized by UV-Visible spectroscopy (where $\mathrm{L}_{3}=m s-5,7,7$, 12,14,14-hexamethyl-1,4,8,11-tetraazacyclotetradecane and $\mathrm{L}_{4}=$ rac- $\mathrm{Me}_{6}[14]-4,11-$ dieneN $\left._{4}\right) .{ }^{19-22}$ The UV spectrum of $\left[\mathrm{NiL}_{1}\left(\mathrm{NO}_{3}\right)_{2}\right] \mathrm{ClO}_{4}\left(\varepsilon_{296}=11,400 \mathrm{M}^{-1}\right.$ $\left.\mathrm{cm}^{-1}, \varepsilon_{370}=5,000 \mathrm{M}^{-1} \mathrm{~cm}^{-1}\right)$ in acidic aqueous solution in the presence of sulphate has been taken. ESR spectrum of the $\left[\mathrm{NiL}_{1}\right]^{3+}$ complex has been taken in acidic aqueous solution in the presence of sulphate. The Ni(III) solution was prepared freshly by dissolving the sample in aqueous acidic solution containing sulphate for stabilizing the $\mathrm{Ni}(\mathrm{III})$. A stock solution of perchloric acid was prepared and was standardized by titration with potassium hydrogen phthalate. A stock solution of copper perchlorate was prepared by neutralizing copper carbonate $(0.0091 \mathrm{~mol}, 2 \mathrm{~g})$ with $70 \%$ perchloric acid $(1.56 \mathrm{ml}, 0.018 \mathrm{~mol})$. The resultant solution was standardized iodometrically.

Caution: Compounds containing perchlorate anions must be regarded as potentially explosive and should be handled with caution.

\subsection{Kinetic studies}

Studies were carried out on the kinetics of oxidation of hydrogen peroxide by $\left[\mathrm{Ni}^{\mathrm{III}} \mathrm{L}_{1}\right]$ under second and first order conditions. The ionic strength was maintained at $0.5 \mathrm{~mol} \mathrm{dm}{ }^{-3}$ using sodium perchlorate. The $\mathrm{pH}$ dependence on the reaction rate was studied by varying the $\mathrm{pH}$ of the medium from 1-1.5 using perchloric acid. The $\mathrm{pH}$ was measured with an Eutech (India) instrument. The concentration of $\left[\mathrm{H}_{2} \mathrm{O}_{2}\right]$ was varied from $2.5 \times 10^{-4}$ to $1.5 \times 10^{-3} \mathrm{~mol} \mathrm{dm}^{-3}$ and the Ni(III) complex concentration was fixed at $5 \times 10^{-5} \mathrm{~mol} \mathrm{dm}^{-3}$. The variation of $[\mathrm{Cu}(\mathrm{II})]$ was extended over the range $5 \times 10^{-6}$ to $1 \times 10^{-4} \mathrm{~mol} \mathrm{dm}^{-3}$. The effect of sulphate on reaction rate was studied by taking its concentration as $0.002 \mathrm{~mol} \mathrm{dm}^{-3}$ in the $\mathrm{pH}$ range 1-2.5. Absorbance changes with time were measured using a 'Shimadzu' UV-Visible recording spectrophotometer (UV-1601). Decrease in absorbance of LMCT band of $\mathrm{Ni}$ (III) was followed at $350 \mathrm{~nm}$. The observed rate constant $\mathrm{k}_{\mathrm{obs}}$ was calculated from the slopes of the linear regression plots of $\ln \left\{1+\left(\mathrm{Y}_{\mathrm{o}}-\mathrm{Y}_{\infty}\right) \Delta_{\mathrm{o}} /\left(\mathrm{Y}_{\mathrm{t}}-\mathrm{Y}_{\infty}\right)[\mathrm{A}]_{\mathrm{o}}\right\}$ (where $\Delta_{\mathrm{o}}=\mathrm{a}\left[\mathrm{B}_{\mathrm{o}}\right]-\mathrm{b}\left[\mathrm{A}_{\mathrm{o}}\right], \mathrm{A}_{\mathrm{o}}$ and $\mathrm{B}_{\mathrm{o}}$ are initial concentrations of oxidant and reductant, respectively) against time for second order and $\ln \left(Y_{t}-Y_{\infty}\right)$ against time for first order conditions. ${ }^{23}$

\section{Results and discussion}

Hydrogen peroxide oxidation by $\left[\mathrm{Ni}^{\mathrm{III}} \mathrm{L}_{1}\right]$ at $\mathrm{pH} 1-1.5$ was studied in the absence of $\mathrm{Cu}(\mathrm{II})$ ion. At this $\mathrm{pH}$ range, hydrogen peroxide oxidation by $\left[\mathrm{Ni}^{\mathrm{III}} \mathrm{L}_{1}\right]$ was found to be very slow. It was suggested that at very high acidic conditions the reduction of $\mathrm{Ni}$ (III) by the peroxy anion is slow because of its weak reducing power. ${ }^{24}$ Uncatalysed redox reaction was observed with $\left[\mathrm{M}(\text { bipy })_{3}\right]^{3+},\left[\mathrm{M}(\operatorname{tacn})_{3}\right]^{3+}$ (where $\mathrm{M}=\mathrm{Ni}, \mathrm{Fe}$ and $\mathrm{Ru}$ ) with evolution of oxygen. ${ }^{12,13}$ The same trend is expected with $\left[\mathrm{Ni}^{\mathrm{III}} \mathrm{L}_{1}\right]$. The kinetic data for the reactions of $\left[\mathrm{Ni}^{\mathrm{III}} \mathrm{L}_{1}\right]$ complex with hydrogen peroxide are consistent with a mechanism involving the reduction 
of $\left[\mathrm{Ni}^{\mathrm{III}} \mathrm{L}_{1}\right]$ by both the undissociated $\mathrm{H}_{2} \mathrm{O}_{2}$ and the peroxide anion $\mathrm{HO}_{2}^{-}\left(\mathrm{pK}_{\mathrm{a}}=11.62\right)$

$$
\begin{array}{r}
{\left[\mathrm{Ni}^{\mathrm{III}} \mathrm{L}_{1}\right]+\mathrm{H}_{2} \mathrm{O}_{2} \stackrel{\mathrm{k}_{1}}{\longrightarrow}\left[\mathrm{Ni}^{\mathrm{II}} \mathrm{L}_{1}\right]+\mathrm{H}_{2} \mathrm{O}_{2}^{+}} \\
{\left[\mathrm{Ni}^{\mathrm{iII}} \mathrm{L}_{1}\right]+\mathrm{HO}_{2}^{-} \stackrel{\mathrm{k}_{2}}{\longrightarrow}\left[\mathrm{Ni}^{\mathrm{II}} \mathrm{L}_{1}\right]+\mathrm{HO}_{2}}
\end{array}
$$

The rate equation is given by

$$
\frac{-\mathrm{d}\left[\mathrm{Ni}^{\mathrm{III}} \mathrm{L}_{1}\right]}{2 \mathrm{dt}}=\mathrm{k}_{1}\left[\mathrm{Ni}^{\mathrm{III}} \mathrm{L}_{1}\right]\left[\mathrm{H}_{2} \mathrm{O}_{2}\right]+\mathrm{k}_{2}\left[\mathrm{Ni}^{\mathrm{III}} \mathrm{L}_{1}\right]\left[\mathrm{HO}_{2}^{-}\right]
$$

$$
\begin{aligned}
& \mathrm{H}_{2} \mathrm{O}_{2} \stackrel{\mathrm{K}_{\mathrm{a}}}{\rightleftharpoons} \mathrm{H}^{+}+\mathrm{HO}_{2}^{-} \\
& \begin{aligned}
\frac{-\mathrm{d}\left[\mathrm{Ni}^{\mathrm{III}} \mathrm{L}_{1}\right]}{2 \mathrm{dt}}= & \mathrm{k}_{1}\left[\mathrm{Ni}^{\mathrm{III}} \mathrm{L}_{1}\right]\left[\mathrm{H}_{2} \mathrm{O}_{2}\right] \\
& +\mathrm{k}_{2} \mathrm{~K}_{\mathrm{a}}\left[\mathrm{Ni}^{\mathrm{III}} \mathrm{L}_{1}\right]\left[\mathrm{H}_{2} \mathrm{O}_{2}\right] /\left[\mathrm{H}^{+}\right]
\end{aligned}
\end{aligned}
$$

$$
\mathrm{k}=\mathrm{k}_{1}+\mathrm{k}_{2} \mathrm{~K}_{\mathrm{a}} /\left[\mathrm{H}^{+}\right]
$$

The negligible intercept $\mathrm{k}_{1}$ was consistent with the small rate constant observed in acidic solution. The rate constants $\mathrm{k}_{2} \mathrm{~K}_{\mathrm{a}}$ at various acid concentration were derived from the slope of $\mathrm{k}$ against $\left[\mathrm{H}^{+}\right]^{-1}$ plot and were presented in figure 1 and table 1 . With 30 -fold

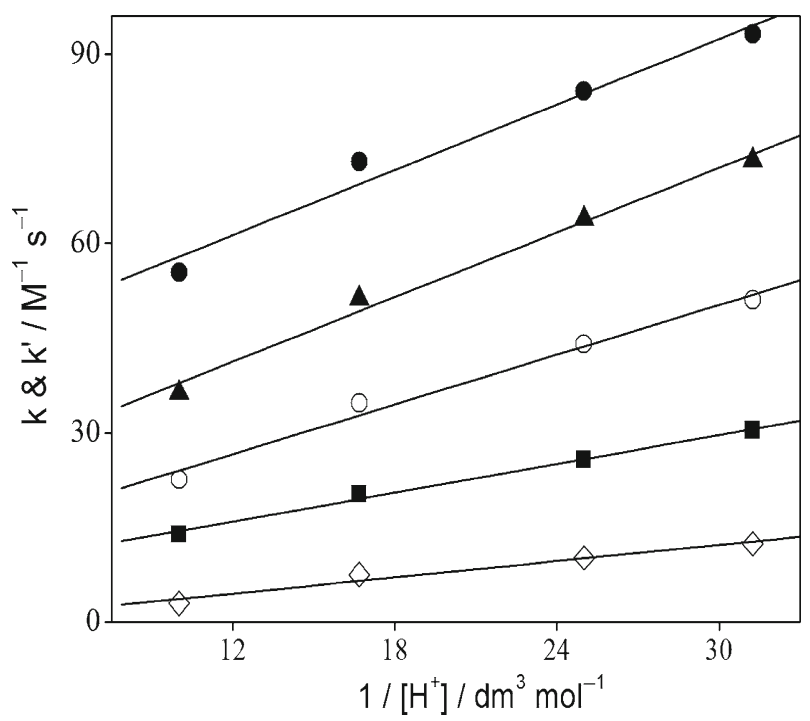

Figure 1. Plot of $\mathrm{k}$ and $\mathrm{k}^{\prime}$ against $1 /\left[\mathrm{H}^{+}\right] ; \mathrm{T}=25^{\circ} \mathrm{C}$; $\left[\mathrm{H}_{2} \mathrm{O}_{2}\right]=2.50 \times 10^{-4} \mathrm{~mol} \mathrm{dm}^{-3} ;\left[\mathrm{Ni}^{\mathrm{III}} \mathrm{L}_{1}\right]=5 \times 10^{-5} \mathrm{~mol}$ $\mathrm{dm}^{-3}, \mathrm{I}=0.50 \mathrm{~mol} \mathrm{dm}{ }^{-3}\left(\mathrm{NaClO}_{4}\right) ;[\mathrm{Cu}(\mathrm{II})] / \mathrm{mol} \mathrm{dm}^{-3}: \diamond$ $-0 * ; \mathbf{\square}-5 \times 10^{-6} ; \bigcirc-1 \times 10^{-5} ; \mathbf{\Delta}-5 \times 10^{-5} ;,-1 \times$ $10^{-4} ; ; *\left[\mathrm{H}_{2} \mathrm{O}_{2}\right]=1.50 \times 10^{-3} \mathrm{~mol} \mathrm{dm}^{-3}$.
Table 1. Dependence of rate on $\mathrm{pH}$ in the absence of $[\mathrm{Cu}(\mathrm{II})] .\left[\mathrm{Ni}^{\mathrm{III}} \mathrm{L}_{1}\right]=5 \times 10^{-5} \mathrm{~mol} \mathrm{dm}^{-3} ;\left[\mathrm{H}_{2} \mathrm{O}_{2}\right]=1.50 \times$ $10^{-3} \mathrm{~mol} \mathrm{dm}^{-3} ; \mathrm{T}=25^{\circ} \mathrm{C} ; \mathrm{I}=0.50 \mathrm{~mol} \mathrm{dm}{ }^{-3}\left(\mathrm{NaClO}_{4}\right)$.

\begin{tabular}{ccc}
\hline $\mathrm{pH}$ & $\mathrm{k} / \mathrm{dm}^{3} \mathrm{~mol}^{-1} \mathrm{~s}^{-1}$ & $\mathrm{k}_{2} \mathrm{~K}_{\mathrm{a}} /\left[\mathrm{H}^{+}\right]$ \\
\hline 1.0 & $2.96 \pm 0.04(4.29)$ & 4.29 \\
1.2 & $7.51 \pm 0.03(7.16)$ & 7.16 \\
1.4 & $10.2 \pm 0.02(10.7)$ & 10.7 \\
1.5 & $12.4 \pm 0.03(13.4)$ & 13.4 \\
\hline
\end{tabular}

Numbers in parentheses are values calculated with use of (6).

increase in concentration of hydrogen peroxide, the rate constants displayed an inverse dependence on the acid concentration. Oxygen evolution occurs but the reduction of metal centre was not observed completely. This complication may be due to the formation of stable $\left[\mathrm{Ni}^{\mathrm{III}} \mathrm{L}_{1} \mathrm{HO}_{2}^{-}\right]$(eq. 7), which acts as strong oxidant than $\left[\mathrm{Ni}^{\mathrm{III}} \mathrm{L}_{1}\right]$, and the oxidation of cyclam ligand.

$$
\left[\mathrm{Ni}^{\mathrm{III}} \mathrm{L}_{1}\right]+\mathrm{HO}_{2}^{-} \rightleftharpoons\left[\mathrm{Ni}^{\mathrm{III}} \mathrm{L}_{1} \mathrm{HO}_{2}^{-}\right]
$$

The decomposition pathway for the superoxide ions formed by reactions (1) an (2) are given by (8) and (9) respectively. ${ }^{13}$

$$
\begin{aligned}
\mathrm{H}_{2} \mathrm{O}_{2}^{+} & \rightleftharpoons \mathrm{H}^{+}+\mathrm{HO}_{2}^{*} \\
2 \mathrm{HO}_{2} & \longrightarrow \mathrm{H}_{2} \mathrm{O}_{2}+\mathrm{O}_{2}
\end{aligned}
$$

In the presence of $\mathrm{Cu}(\mathrm{II})$, the metal centre reduction takes place more rapidly when compared with cyclam ligand oxidation. Most of the reactions involving hydrogen peroxide are carried out at higher $\mathrm{pH}(\mathrm{pH}>5)$ and $\mathrm{HO}_{2}^{-}$is responsible for the decomposition of $\mathrm{H}_{2} \mathrm{O}_{2}$. It is obvious that the oxidation of $\mathrm{H}_{2} \mathrm{O}_{2}$ by $\mathrm{Cu}$ (II) is more favourable in alkaline medium and the rate of decomposition of $\mathrm{H}_{2} \mathrm{O}_{2}$ by $\mathrm{Cu}$ (II) alone at low $\mathrm{pH}$ is considered negligible compared with the decomposition of $\mathrm{H}_{2} \mathrm{O}_{2}$ by $\left[\mathrm{Ni}^{\mathrm{III}} \mathrm{L}_{1}\right]$ complex. Interaction of $\mathrm{Cu}(\mathrm{II})$ with $\left[\mathrm{Ni}^{\mathrm{III}} \mathrm{L}_{1}\right]$ complexes in aqueous acidic condition was ruled out. ${ }^{25}$

The $\mathrm{Cu}$ (II) ion catalysed oxidation of $\mathrm{H}_{2} \mathrm{O}_{2}$ by $\left[\mathrm{Ni}^{\mathrm{III}} \mathrm{L}_{1}\right]$ complex, in the $\mathrm{pH}$ range $1<\mathrm{pH}<1.5$ studied, was found to be fast. The second order rate constants at various $[\mathrm{Cu}(\mathrm{II})]$ ranging from $5 \times 10^{-6}$ to $1 \times$ $10^{-4} \mathrm{~mol} \mathrm{dm}^{-3}$ showed an inverse dependence on the acid concentration (table 2).

It was also pointed out that the promoting action of $\mathrm{Cu}$ (II) ions has been considered due to their ready reducibility to transient $\mathrm{Cu}(\mathrm{I})$ ions. In this redox reaction, oxygen evolution takes place which suggests the formation of copper-peroxo complexs. ${ }^{26-30}$ In aqueous medium, formation of highly labile species (eq. 10) and 
Table 2. Dependence of rate on $[\mathrm{Cu}(\mathrm{II})]$ at various $\mathrm{pH}$. $\left[\mathrm{Ni}^{\mathrm{III}} \mathrm{L}_{1}\right]=5 \times 10^{-5} \mathrm{~mol} \mathrm{dm}^{-3} ;\left[\mathrm{H}_{2} \mathrm{O}_{2}\right]=2.50 \times 10^{-5} \mathrm{~mol}$ $\mathrm{dm}^{-3} ; \mathrm{T}=25^{\circ} \mathrm{C} ; \mathrm{I}=0.50 \mathrm{~mol} \mathrm{dm}^{-3}\left(\mathrm{NaClO}_{4}\right)$.

\begin{tabular}{cccc}
\hline $\mathrm{pH}$ & {$[\mathrm{Cu}(\mathrm{II})] / \mathrm{mol} \mathrm{dm}^{-3}$} & $\mathrm{k}^{\prime} / \mathrm{dm}^{3} \mathrm{~mol}^{-1} \mathrm{~s}^{-1}$ & $\mathrm{k}_{\mathrm{b}} \mathrm{K}_{\mathrm{a}} /\left[\mathrm{H}^{+}\right]$ \\
\hline 1.0 & $5 \times 10^{-6}$ & $13.9 \pm 0.03(14.4)$ & 7.61 \\
& $1 \times 10^{-5}$ & $22.6 \pm 0.04(24.0)$ & 13.1 \\
& $5 \times 10^{-5}$ & $36.3 \pm 0.05(37.9)$ & 17.1 \\
& $1 \times 10^{-4}$ & $55.4 \pm 0.02(57.9)$ & 17.3 \\
1.2 & $5 \times 10^{-6}$ & $20.3 \pm 0.04(19.5)$ & 12.7 \\
& $1 \times 10^{-5}$ & $34.7 \pm 0.02(32.8)$ & 21.9 \\
& $5 \times 10^{-5}$ & $51.3 \pm 0.02(49.2)$ & 28.4 \\
1.4 & $1 \times 10^{-4}$ & $72.9 \pm 0.03(69.4)$ & 28.8 \\
& $5 \times 10^{-6}$ & $25.7 \pm 0.03(25.8)$ & 19.0 \\
& $1 \times 10^{-5}$ & $44.1 \pm 0.05(43.7)$ & 32.8 \\
& $5 \times 10^{-5}$ & $63.9 \pm 0.03(63.4)$ & 42.6 \\
1.5 & $1 \times 10^{-4}$ & $84.1 \pm 0.04(83.8)$ & 43.1 \\
& $5 \times 10^{-6}$ & $30.4 \pm 0.03(30.6)$ & 23.7 \\
& $1 \times 10^{-5}$ & $51.0 \pm 0.05(51.9)$ & 41.0 \\
& $5 \times 10^{-5}$ & $73.2 \pm 0.02(74.1)$ & 53.3 \\
& $1 \times 10^{-4}$ & $93.2 \pm 0.02(94.6)$ & 53.9 \\
\hline
\end{tabular}

Numbers in parentheses are values calculated with use of (17).

successive electron transfer reaction with $\left[\mathrm{Ni}^{\mathrm{III}} \mathrm{L}_{1}\right]$ may be given in the following scheme 2 .

$$
\begin{aligned}
\mathrm{Cu}^{\mathrm{II}}+\mathrm{H}_{2} \mathrm{O}_{2} & \rightleftharpoons \mathrm{Cu}^{\mathrm{II}} \mathrm{H}_{2} \mathrm{O}_{2} \rightleftharpoons \mathrm{Cu}_{2} \mathrm{H}_{2} \mathrm{O}_{2}^{+} \\
\mathrm{Cu}_{2} \mathrm{H}_{2} \mathrm{O}_{2}^{+} & \rightleftharpoons \mathrm{Cu}^{\mathrm{I}}(\mathrm{aq})+\mathrm{H}_{2} \dot{\mathrm{O}}_{2}^{+} \\
\mathrm{Cu}^{\mathrm{I}}(\mathrm{aq})+\mathrm{Ni}^{\mathrm{II}} \mathrm{L}_{1} & \rightleftharpoons \mathrm{Cu}^{\mathrm{II}}(\mathrm{aq})+\mathrm{Ni}^{\mathrm{II}} \mathrm{L}_{1}
\end{aligned}
$$

Scheme 2. Equilibrium pathways for the interaction of copper(II) ion with hydrogen peroxide.

The rate expression for $\mathrm{Cu}(\mathrm{II})$ catalysed hydrogen peroxide oxidation may be written as shown in equation 11 .

$$
\begin{array}{r}
\mathrm{Cu}^{\mathrm{II}}+\mathrm{H}_{2} \mathrm{O}_{2} \stackrel{\mathrm{K}_{1}}{\rightleftharpoons} \mathrm{Cu}^{1} \mathrm{H}_{2} \mathrm{O}_{2}^{\cdot+} \\
{\left[\mathrm{Ni}^{\mathrm{III}} \mathrm{L}_{1}\right]+\mathrm{Cu}^{\mathrm{I}} \mathrm{H}_{2} \mathrm{O}_{2}^{\cdot+} \stackrel{\mathrm{k}_{3}}{\longrightarrow}\left[\mathrm{Ni}^{\mathrm{II}} \mathrm{L}_{1}\right]+\mathrm{Cu}^{\mathrm{II}}+\mathrm{H}_{2} \mathrm{O}_{2}^{\cdot+}}
\end{array}
$$

The peroxy anion might react with both $\mathrm{Cu}(\mathrm{II})$ and $\left[\mathrm{Ni}^{\mathrm{III}} \mathrm{L}_{1}\right]$. The $\left[\mathrm{Ni}^{\mathrm{III}} \mathrm{L}_{1} \mathrm{HO}_{2}^{-}\right]$formed is a stable oxidant and the preferable reaction pathway involves interaction of $\left[\mathrm{Cu}^{\mathrm{II}} \mathrm{HO}_{2}^{-}\right]$with $\left[\mathrm{Ni}^{\mathrm{III}} \mathrm{L}_{1}\right]$. The possible equilibrium may be represented by the following sequence, scheme 3 .

The rate equation for the $\mathrm{Cu}(\mathrm{II})$ ion promoted peroxy anion may be given by the equation 13 .

$$
\mathrm{Cu}^{\mathrm{II}}+\mathrm{HO}_{2}^{-} \stackrel{\mathrm{K}_{2}}{\rightleftharpoons} \mathrm{Cu}^{\mathrm{I}} \mathrm{HO}_{2}
$$

$$
\left[\mathrm{Ni}^{\mathrm{III}} \mathrm{L}_{1}\right]+\mathrm{Cu}^{\mathrm{I}} \mathrm{HO}_{2} \stackrel{\mathrm{k}_{4}}{\longrightarrow}\left[\mathrm{Ni}^{\mathrm{II}} \mathrm{L}_{1}\right]+\mathrm{Cu}^{\mathrm{II}}+\mathrm{HO}_{2}
$$

The rate expression involving uncatalysed and catalysed hydrogen peroxide oxidation by $\left[\mathrm{Ni}^{\mathrm{III}} \mathrm{L}_{1}\right]$ is shown by the following rate equations:vspace* $3 \mathrm{pt}$

$$
\begin{aligned}
\frac{-\mathrm{d}\left[\mathrm{Ni}^{\mathrm{III}} \mathrm{L}_{1}\right]}{2 \mathrm{dt}=} & \mathrm{k}_{1}\left[\mathrm{Ni}^{\mathrm{III}} \mathrm{L}_{1}\right]\left[\mathrm{H}_{2} \mathrm{O}_{2}\right] \\
& +\mathrm{k}_{2}\left[\mathrm{Ni}^{\mathrm{III}} \mathrm{L}_{1}\right]\left[\mathrm{HO}_{2}^{-}\right] \\
& +\mathrm{k}_{3}\left[\mathrm{Ni}^{\mathrm{III}} \mathrm{L}_{1}\right]\left[\mathrm{Cu}^{\mathrm{I}} \mathrm{H}_{2} \mathrm{O}_{2}^{+}\right] \\
& +\mathrm{k}_{4}\left[\mathrm{Ni}^{\mathrm{III}} \mathrm{L}_{1}\right]\left[\mathrm{Cu}^{\mathrm{I}} \mathrm{HO}_{2}^{\prime}\right] \\
\frac{-\mathrm{d}\left[\mathrm{Ni}^{\mathrm{III}} \mathrm{L}_{1}\right]}{2 \mathrm{dt}}= & \mathrm{k}_{1}\left[\mathrm{Ni}^{\mathrm{III}} \mathrm{L}_{1}\right]\left[\mathrm{H}_{2} \mathrm{O}_{2}\right] \\
& +\mathrm{k}_{2} \mathrm{~K}_{\mathrm{a}}\left[\mathrm{Ni}^{\mathrm{III}} \mathrm{L}_{1}\right]\left[\mathrm{H}_{2} \mathrm{O}_{2}\right] /\left[\mathrm{H}^{+}\right] \\
& +\mathrm{k}_{3} \mathrm{~K}_{1}\left[\mathrm{Ni}^{\mathrm{III}} \mathrm{L}_{1}\right]\left[\mathrm{H}_{2} \mathrm{O}_{2}\right]\left[\mathrm{Cu}^{\mathrm{II}}\right] \\
& +\mathrm{k}_{4} \mathrm{~K}_{2} \mathrm{~K}_{\mathrm{a}}\left[\mathrm{Ni}^{\mathrm{III}} \mathrm{L}_{1}\right]\left[\mathrm{H}_{2} \mathrm{O}_{2}\right]\left[\mathrm{Cu}^{\mathrm{II}}\right] /\left[\mathrm{H}^{+}\right] \\
& \\
\mathrm{k}^{\prime}=\quad & \left.\mathrm{k}_{1}+\mathrm{k}_{3} \mathrm{~K}_{1}\left[\mathrm{Cu}^{\mathrm{II}}\right]\right) \\
+ & \mathrm{K}_{\mathrm{a}}\left(\mathrm{k}_{2}+\mathrm{k}_{4} \mathrm{~K}_{2}\left[\mathrm{Cu}^{\mathrm{II}}\right]\right) /\left[\mathrm{H}^{+}\right]
\end{aligned}
$$

where $\mathrm{k}_{\mathrm{a}}\left(=\mathrm{k}_{1}+\mathrm{k}_{3} \mathrm{~K}_{1}\left[\mathrm{Cu}^{\mathrm{II}}\right]\right)$ was obtained from intercept and $\mathrm{k}_{\mathrm{b}} \mathrm{K}_{\mathrm{a}}\left(\mathrm{k}_{\mathrm{b}}=\mathrm{k}_{2}+\mathrm{k}_{4} \mathrm{~K}_{2}\left[\mathrm{Cu}^{\mathrm{II}}\right]\right.$ was obtained from 


$$
\begin{gathered}
\mathrm{Cu}^{\mathrm{II}}+\mathrm{HO}_{2}^{-} \rightleftharpoons \mathrm{Cu}^{\mathrm{II}} \mathrm{HO}_{2}^{-} \rightleftharpoons \mathrm{Cu}^{\mathrm{I}} \mathrm{HO}_{2}^{-} \\
{\left[\mathrm{Ni}^{\mathrm{II}} \mathrm{L}_{1} \mathrm{HO}_{2}^{-}\right]+\mathrm{Cu}^{\mathrm{II}} \rightleftharpoons\left[\mathrm{Ni}^{\mathrm{III}} \mathrm{L}_{1}\right]+\mathrm{Cu}^{\mathrm{II}} \mathrm{HO}_{2}^{-} \rightleftharpoons\left[\mathrm{Ni}^{\mathrm{III}} \mathrm{L}_{1} \mathrm{HO}_{2}^{-} \mathrm{Cu}^{\mathrm{II}}\right]}
\end{gathered}
$$

Scheme 3. Equilibrium pathways for the interaction of copper(II) ion with peroxy anion.

slope of $\mathrm{k}^{\prime}$ against $\left[\mathrm{H}^{+}\right]^{-1}$ plot (figure 1). Activation of $\mathrm{H}_{2} \mathrm{O}_{2}$ increases by increasing the $[\mathrm{Cu}(\mathrm{II})]$ and was observed by the increase in the rate constant (table 2). The influence of copper(II) ions on reaction kinetics was observed from the plot of $\log \mathrm{k}^{\prime}$ against $\log \left[\mathrm{Cu}^{\mathrm{II}}\right]$ with a slope of 0.44 at $\mathrm{pH} 1$ (figure 2).

\subsection{Sulphate dependence}

Between the $\mathrm{pH} 1$ and 2.5, the oxidation kinetics was studied at sulphate ion concentration of $0.002 \mathrm{~mol} \mathrm{dm}^{-3}$ and copper(II) ion concentration of $1 \times 10^{-4} \mathrm{~mol} \mathrm{dm}^{-3}$. Variation of sulphate ion concentration at constant $\mathrm{pH}$ 2 has also been studied. In the presence of sulphate, the rate constant is found to decrease.

In sulphate medium, $\left[\mathrm{Ni}^{\mathrm{III}} \mathrm{L}_{1}\right]$ exist as sulphatocomplex according to the equation 18. The factors such as stabilization of the complex by hydrogen bonding and the lower reduction potential ${ }^{21}$ of $\left[\mathrm{NiL}_{1}\left(\mathrm{SO}_{4}\right)\right]^{+}$are considered to retard the hydrogen peroxide oxidation in the presence of sulphate. Also formation of copper sulphate which is a weak catalyst might reduce the availability of free $\mathrm{Cu}$ (II) towards the promoting action.

$$
\begin{array}{r}
{\left[\mathrm{Ni}^{\mathrm{III}} \mathrm{L}_{1}\right]^{3+}+\mathrm{SO}_{4}^{2-} \stackrel{\mathrm{K}_{\mathrm{f}}}{\rightleftharpoons}\left[\mathrm{Ni}^{\mathrm{III}} \mathrm{L}_{1} \mathrm{SO}_{4}\right]^{+}} \\
\mathrm{Cu}_{(\mathrm{aq})}^{\mathrm{II}}+\mathrm{SO}_{4(\mathrm{aq})}^{2-} \rightleftharpoons \mathrm{CuSO}_{4(\mathrm{aq})}
\end{array}
$$

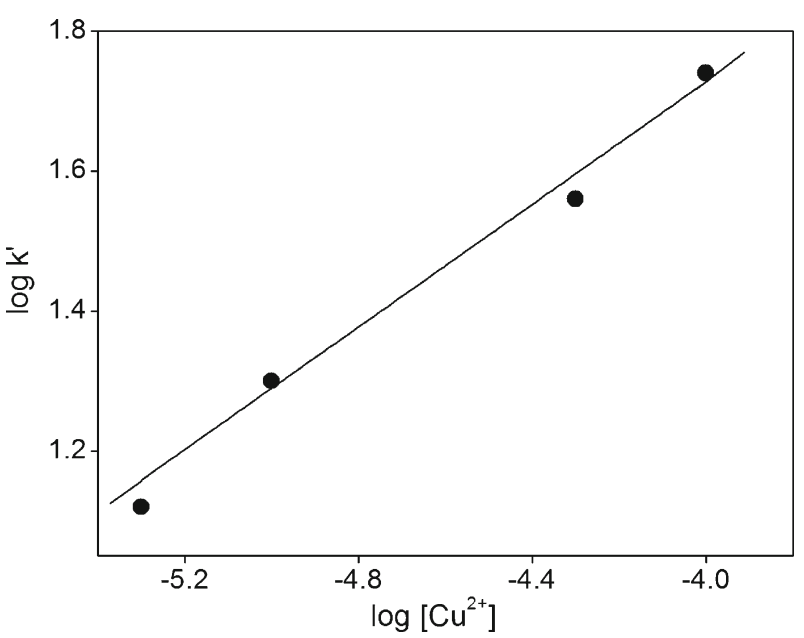

Figure 2. Plot of $\log \mathrm{k}^{\prime}$ against $1 /\left[\mathrm{H}^{+}\right] ; \mathrm{T}=25^{\circ} \mathrm{C}$; $\left[\mathrm{H}_{2} \mathrm{O}_{2}\right]=2.5 \times 10^{-4} \mathrm{~mol} \mathrm{dm}{ }^{-3} ;$ [complex] $=5 \times 10^{-5} \mathrm{~mol}$ $\mathrm{dm}^{-3} ; \mathrm{I}=0.50 \mathrm{~mol} \mathrm{dm}^{-3}\left(\mathrm{NaClO}_{4}\right), \mathrm{pH}=1$.
In the presence of sulphate and $\mathrm{Cu}(\mathrm{II})$ ion, the kinetic pathways (20) and (21) are presented.

$$
\begin{aligned}
& {\left[\mathrm{Ni}^{\mathrm{III}} \mathrm{L}_{1}\left(\mathrm{SO}_{4}\right)\right]^{+}+\mathrm{Cu}^{\mathrm{I}} \mathrm{H}_{2} \mathrm{O}_{2}^{\cdot+}} \\
& \stackrel{\mathrm{k}_{5}}{\longrightarrow}\left[\mathrm{Ni}^{\mathrm{II}} \mathrm{L}_{1}\right]+\mathrm{SO}_{4}^{2-}+\mathrm{Cu}^{\mathrm{II}}+\mathrm{H}_{2} \mathrm{O}_{2}^{\cdot+} \\
& \stackrel{\left[\mathrm{Ni}^{\mathrm{III}} \mathrm{L}_{1}\left(\mathrm{SO}_{4}\right)\right]^{+}+\mathrm{Cu}^{\mathrm{I}} \mathrm{HO}_{2}^{\cdot}}{\stackrel{\mathrm{k}_{6}}{\longrightarrow}\left[\mathrm{Ni}^{\mathrm{II}} \mathrm{L}_{1}\right]+\mathrm{SO}_{4}^{2-}+\mathrm{Cu}^{\mathrm{II}}+\mathrm{HO}_{2}^{\cdot}}
\end{aligned}
$$

The overall rate expression including uncatalysed (eq. 1,2$)$ catalysed $(11,13)$ and the presence of sulphate (eq. 20, 21) for the oxidation of $\mathrm{H}_{2} \mathrm{O}_{2}$ by $\left[\mathrm{Ni}^{\mathrm{III}} \mathrm{L}_{1}\right]$ may involve the following steps:

$$
\begin{aligned}
& \frac{-\mathrm{d}\left[\mathrm{Ni}^{\mathrm{III}} \mathrm{L}_{1}\right]}{2 \mathrm{dt}} \\
& =\mathrm{k}_{1}\left[\mathrm{Ni}^{\mathrm{III}} \mathrm{L}_{1}\right]\left[\mathrm{H}_{2} \mathrm{O}_{2}\right] \\
& +\mathrm{k}_{3} \mathrm{~K}_{1}\left[\mathrm{Ni}^{\mathrm{III}} \mathrm{L}_{1}\right]\left[\mathrm{H}_{2} \mathrm{O}_{2}\right]\left[\mathrm{Cu}^{\mathrm{II}}\right] \\
& +\mathrm{k}_{5} \mathrm{~K}_{\mathrm{f}} \mathrm{K}_{1}\left[\mathrm{Ni}^{\mathrm{III}} \mathrm{L}_{1}\right]\left[\mathrm{SO}_{4}\right]\left[\mathrm{H}_{2} \mathrm{O}_{2}\right]\left[\mathrm{Cu}^{\mathrm{II}}\right] \\
& +\mathrm{k}_{2} \mathrm{~K}_{\mathrm{a}}\left[\mathrm{Ni}^{\mathrm{III}} \mathrm{L}_{1}\right]\left[\mathrm{H}_{2} \mathrm{O}_{2}\right] /\left[\mathrm{H}^{+}\right] \\
& +\mathrm{k}_{4} \mathrm{~K}_{2} \mathrm{~K}_{\mathrm{a}}\left[\mathrm{Ni}^{\mathrm{III}} \mathrm{L}_{1}\right]\left[\mathrm{H}_{2} \mathrm{O}_{2}\right]\left[\mathrm{Cu}^{\mathrm{II}}\right] /\left[\mathrm{H}^{+}\right] \\
& +\mathrm{k}_{6} \mathrm{~K}_{2} \mathrm{~K}_{\mathrm{f}} \mathrm{K}_{\mathrm{a}}\left[\mathrm{Ni}^{\mathrm{III}} \mathrm{L}_{1}\right]\left[\mathrm{SO}_{4}\right]\left[\mathrm{H}_{2} \mathrm{O}_{2}\right]\left[\mathrm{Cu}^{\mathrm{II}}\right] /\left[\mathrm{H}^{+}\right] \\
& k^{\prime \prime}=\left(\mathrm{k}_{1}+\mathrm{k}_{3} \mathrm{~K}_{1}\left[\mathrm{Cu}^{\mathrm{II}}\right]+\mathrm{k}_{5} \mathrm{~K}_{1} \mathrm{~K}_{\mathrm{f}}\left[\mathrm{Cu}^{\mathrm{II}}\right]\left[\mathrm{SO}_{4}\right]\right) \\
& +\mathrm{K}_{\mathrm{a}}\left(\mathrm{k}_{2}+\mathrm{k}_{4} \mathrm{~K}_{2}\left[\mathrm{Cu}^{\mathrm{II}}\right]\right. \\
& \left.+\mathrm{k}_{6} \mathrm{~K}_{\mathrm{f}} \mathrm{K}_{2}\left[\mathrm{Cu}^{\mathrm{II}}\right]\left[\mathrm{SO}_{4}\right]\right) /\left[\mathrm{H}^{+}\right] \\
& \mathrm{k}^{\prime \prime}=\mathrm{k}_{\mathrm{c}}+\mathrm{k}_{\mathrm{d}} \mathrm{K}_{\mathrm{a}} /\left[\mathrm{H}^{+}\right]
\end{aligned}
$$

In the rate law equation $24, \mathrm{k}_{\mathrm{c}}\left(=\mathrm{k}_{1}+\mathrm{k}_{3} \mathrm{~K}_{1}\left[\mathrm{Cu}^{\mathrm{II}}\right]+\right.$ $\left.\mathrm{k}_{5} \mathrm{~K}_{1} \mathrm{~K}_{\mathrm{f}}\left[\mathrm{Cu}^{\mathrm{II}}\right]\left[\mathrm{SO}_{4}\right]\right)$ and $\mathrm{k}_{\mathrm{d}} \mathrm{K}_{\mathrm{a}}\left(\mathrm{k}_{\mathrm{d}}=\mathrm{k}_{2}+\mathrm{k}_{4} \mathrm{~K}_{2}\left[\mathrm{Cu}^{\mathrm{II}}\right]+\right.$ $\mathrm{k}_{6} \mathrm{~K}_{\mathrm{f}} \mathrm{K}_{2}\left[\mathrm{Cu}^{\mathrm{II}}\right]\left[\mathrm{SO}_{4}\right]$ ) were obtained from intercept and slope of the plot of $\mathrm{k}^{\prime \prime}$ against $\left[\mathrm{H}^{+}\right]^{-1}$, respectively (figure 3 and table 3 ).

\subsection{Interpretation of ligand oxidation}

In order to confirm the involvement of $\mathrm{HO}_{2}^{-}$with $\mathrm{Ni}$ (III) centre and oxidation of ligand by ${ }^{\circ} \mathrm{OH}$ radical, the 


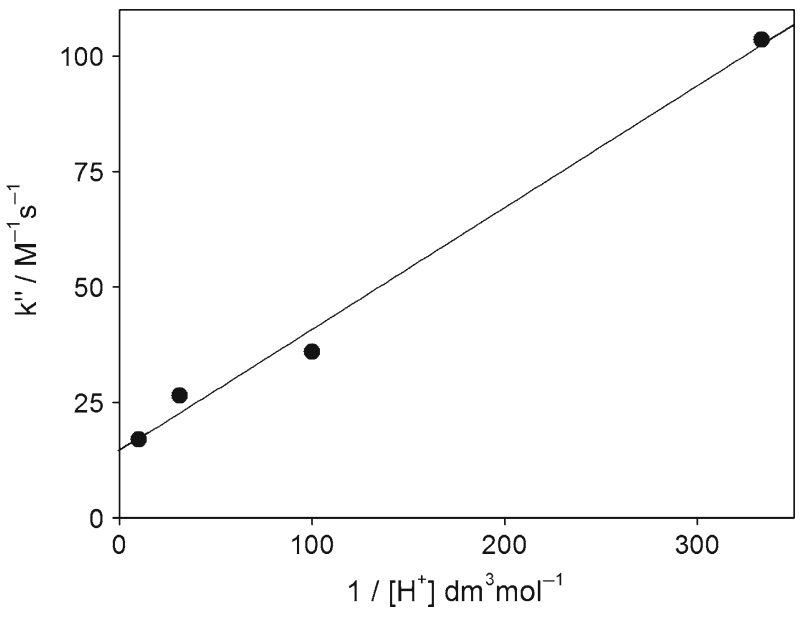

Figure 3. Plot of $\mathrm{k}^{\prime \prime}$ against $1 /\left[\mathrm{H}^{+}\right] ; \mathrm{T}=25^{\circ} \mathrm{C} ;\left[\mathrm{H}_{2} \mathrm{O}_{2}\right]=$ $2.5 \times 10^{-4} \mathrm{~mol} \mathrm{dm}^{-3} ;$ [complex] $=5 \times 10^{-5} \mathrm{~mol} \mathrm{dm}^{-3}$; $\mathrm{I}=0.50 \mathrm{~mol} \mathrm{dm}^{-3}\left(\mathrm{NaClO}_{4}\right),[\mathrm{Cu}(\mathrm{II})]=1 \times 10^{-4} \mathrm{~mol}$ $\mathrm{dm}^{-3} ;\left[\mathrm{Na}_{2} \mathrm{SO}_{4}\right]=\bullet-0.002 \mathrm{~mol} \mathrm{dm}^{-3}$.

reaction was interpreted on the basis of the observations from the following reactions:

\section{2a Study of the reaction of ${ }^{\circ} \mathrm{OH}$ radical: Spectral} scans of metal centred reduction of $\left[\mathrm{Ni}^{\mathrm{III}} \mathrm{L}_{1}\right]$ was studied under first order conditions (20-fold of $\mathrm{H}_{2} \mathrm{O}_{2}$ ) both in the presence and absence of $\mathrm{Cu}(\mathrm{II})$ and in the presence of sulphate at $\mathrm{pH} 1$. After the complete disappearance of LMCT band of $\left[\mathrm{Ni}^{\mathrm{III}} \mathrm{L}_{1}\right]$ at $300 \mathrm{~nm}$, the increases in the intense peak at $284 \mathrm{~nm}$ and at $522 \mathrm{~nm}$ with development of pink colour was observed (figure 4 a). Similar observations were made with $\left[\mathrm{NiL}_{1}\right]^{2+}$ in the present study. McAuley suggested that it was due to the transient $\mathrm{Ni}(\mathrm{III})($ hydroxo)ion and the hydroxyl radical ${ }^{17}$ which leads to diimine followed by the formation of pink dimeric species. The crystal structure of $\left[\mathrm{NiL}_{1}\left(\mathrm{NO}_{3}\right)_{2}\right]\left(\mathrm{NO}_{3}\right)$ showed the cyclam to be in a transIII conformation with the two secondary amines of the six-member ring cis to each other. This configuration would permit dehydrogenation in the ring.
In the spectral scans of the oxidation of $\left[\mathrm{NiL}_{2}\right]\left(\mathrm{ClO}_{4}\right)_{2} \quad\left(\mathrm{~L}_{2}=\right.$ 1,8-bis(2-hydroxyethyl)-1,3,6, $8,10,13$-hexaazacyclotetradecane) by hydrogen peroxide both in the absence and presence of $\mathrm{Cu}$ (II) and in the presence of sulphate at $\mathrm{pH} 1$ no such pink species with an intense peak at $520 \mathrm{~nm}$ was observed (figure $4 \mathrm{~b}$ ). Instead, a peak at $270 \mathrm{~nm}$ and a shoulder near $325 \mathrm{~nm}$ were formed rapidly. The intensity of the shoulder at $325 \mathrm{~nm}$ gradually decreases and reaches a limit at $270 \mathrm{~nm}$.

Hydrogen peroxide has no effect on both $\left[\mathrm{NiL}_{3}\right]\left(\mathrm{ClO}_{4}\right)_{2}$ and $\left[\mathrm{NiL}_{4}\right]\left(\mathrm{ClO}_{4}\right)_{2}$. The CTTS band of these complexes was affected only slightly. From the UV spectrum of $\left[\mathrm{NiL}_{4}\right]\left(\mathrm{ClO}_{4}\right)_{2}$, it was found that the peak formed at $280 \mathrm{~nm}$ of $\left[\mathrm{NiL}_{2}\right]^{2+}$ and $270 \mathrm{~nm}$ of $\left[\mathrm{NiL}_{1}\right]\left(\mathrm{ClO}_{4}\right)_{2}$ by reaction with hydrogen peroxide may be due to $\pi \rightarrow \pi^{*}$ transition of $\mathrm{C}=\mathrm{N}$. Therefore, it may be concluded that the reaction of $\mathrm{Ni}$ (III) complex with hydrogen peroxide is accompanied by abstraction of ' $\mathrm{H}$ ' atom from the macrocyclic ligand. But in the presence of $\mathrm{Cu}(\mathrm{II})$, reduction of $\mathrm{Ni}(\mathrm{III})$ to $\mathrm{Ni}(\mathrm{II})$ is faster than the abstraction of $\mathrm{H}$ atom.

3.2b Effect of isopropyl alcohol: The involvement of 'OH radical can be understood by carrying out the kinetics of oxidation of hydrogen peroxide by $\mathrm{Ni}(\mathrm{III}) \mathrm{com}-$ plex in the presence of 2-propanol. The ${ }^{\circ} \mathrm{OH}$ radical tend to abstract hydrogen both from macrocylic ligand and isopropyl alcohol.

$$
\begin{gathered}
\mathrm{HC}\left(\mathrm{CH}_{3}\right)_{2} \mathrm{OH}+{ }^{\circ} \mathrm{OH} \rightarrow{ }^{\circ} \mathrm{C}\left(\mathrm{CH}_{3}\right)_{2} \mathrm{OH}+\mathrm{H}_{2} \mathrm{O} \\
\mathrm{NiL}^{3+}+{ }^{\cdot} \mathrm{C}\left(\mathrm{CH}_{3}\right)_{2} \mathrm{OH} \rightarrow\left(\mathrm{CH}_{3}\right)_{2} \mathrm{CO}+\mathrm{NiL}^{2+}+\mathrm{H}^{+}
\end{gathered}
$$

The plot of $\mathrm{k}^{\prime \prime}$ against [isopropyl alcohol] (table 4, figure 5) was linear with a positive slope and there is no effect up to an isopropyl alcohol concentration of $1 \mathrm{~mol}$ $\mathrm{dm}^{-3}$. Since the reaction of $\mathrm{HO}_{2}^{-}$is faster than ${ }^{\circ} \mathrm{OH},{ }^{31}$ the promoting action of $\mathrm{Cu}(\mathrm{II})$ ion is not affected in the

Table 3. Dependence of rate on sulphate. [Complex] = $5 \times 10^{-5} \mathrm{~mol} \mathrm{dm}^{-3} ;\left[\mathrm{H}_{2} \mathrm{O}_{2}\right]=2.50 \times 10^{-5} \mathrm{~mol} \mathrm{dm}^{-3} ; \mathrm{T}=25^{\circ} \mathrm{C}$;

\begin{tabular}{|c|c|c|c|c|}
\hline \multicolumn{3}{|c|}{$\left[\mathrm{Na}_{2} \mathrm{SO}_{4}\right] \quad 0.002 \mathrm{~mol} \mathrm{dm}^{-3}$} & \multicolumn{2}{|c|}{ pH 2} \\
\hline $\mathrm{pH}$ & $\begin{array}{c}\mathrm{k}^{\prime \prime} / \\
\mathrm{dm}^{3} \mathrm{~mol}^{-1} \mathrm{~s}^{-1}\end{array}$ & $\mathrm{k}_{\mathrm{d}} \mathrm{K}_{\mathrm{a}} /\left[\mathrm{H}^{+}\right]$ & $\begin{array}{l}{\left[\mathrm{SO}_{4}^{2-}\right]} \\
\mathrm{mol} \mathrm{dm}\end{array}$ & $\begin{array}{c}\mathrm{k}^{\prime \prime} / \\
\mathrm{dm}^{3} \mathrm{~mol}^{-1} \mathrm{~s}^{-1}\end{array}$ \\
\hline 1.0 & $17.0 \pm 0.02(17.2)$ & 2.63 & 0.001 & $52.0 \pm 0.04$ \\
\hline 1.5 & $26.5 \pm 0.03(22.8)$ & 8.23 & 0.002 & $36.0 \pm 0.03$ \\
\hline 2.0 & $36.0 \pm 0.03(40.9)$ & 26.3 & 0.005 & $26.3 \pm 0.06$ \\
\hline 2.5 & $104 \pm 0.01(102)$ & 87.7 & & \\
\hline
\end{tabular}
$[\mathrm{Cu}(\mathrm{II})]=1 \times 10^{-4} \mathrm{~mol} \mathrm{dm}^{-3} ; \mathrm{I}=0.50 \mathrm{~mol} \mathrm{dm}^{-3}\left(\mathrm{NaClO}_{4}\right)$.

Numbers in parentheses are values calculated with use of (24). 


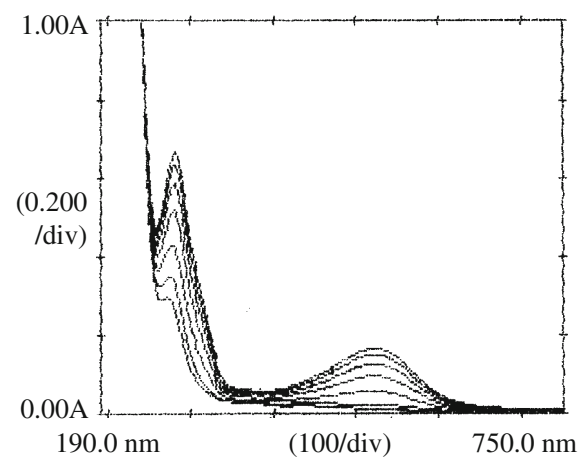

(a) $\left[\mathrm{NiL}_{1}\right]^{2+}$

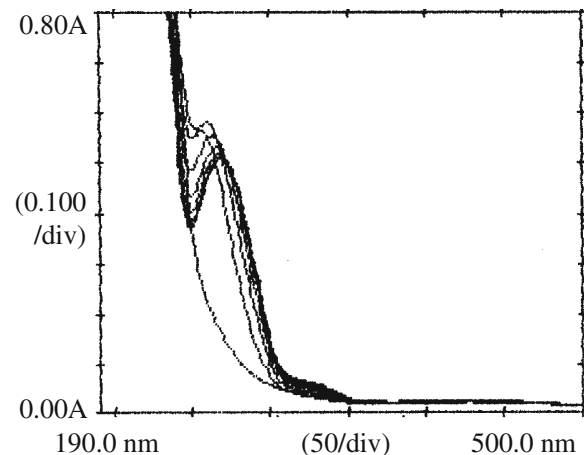

(b) $\left[\mathrm{NiL}_{2}\right]^{2+}$

Figure 4. Spectral scans observed for the oxidation of macrocyclic ligands $(\mathrm{L}=$ $\mathrm{L}_{1}$ and $\mathrm{L}_{2}$ ) of $\mathrm{Ni}(\mathrm{II})$ complexes by hydrogen peroxide: $[\mathrm{NiL}]^{2+}$ complexes $=2 \times$ $10^{-4} \mathrm{~mol} \mathrm{dm}^{-3} ;\left[\mathrm{Na}_{2} \mathrm{SO}_{4}\right]=0.001 \mathrm{~mol} \mathrm{dm}^{-3} ;\left[\mathrm{H}_{2} \mathrm{O}_{2}\right]=4 \times 10^{-3} \mathrm{~mol} \mathrm{dm}^{-3} ; \mathrm{pH}=$ $1\left(\mathrm{HClO}_{4}\right) ; \mathrm{I}=0.50 \mathrm{~mol} \mathrm{dm}^{-3}\left(\mathrm{NaClO}_{4}\right)$. Scans $(\mathbf{a})$ and $(\mathbf{b})$ measured at $900 \mathrm{~s}$ intervals in the absence of $\mathrm{Cu}$ (II).

oxidation of $\mathrm{H}_{2} \mathrm{O}_{2}$ than the interaction of $\cdot \mathrm{OH}$ radical with macrocyclic complex in acidic medium. The interaction of ${ }^{\cdot} \mathrm{OH}$ is observed after the reduction of $\mathrm{Ni}$ (III) centre. It was suggested that $\mathrm{H}_{2} \mathrm{O}_{2}$ reacts with $\mathrm{NiL}^{2+}$ by a Fenton-type mechanism. Therefore, the effect of isopropyl alcohol at lower concentration has not been observed.

It was hence concluded that the $\mathrm{HO}_{2}^{-}$would be the reacting species rather than $\mathrm{OH}$ radical. The rate of decomposition of $\mathrm{Ni}$ (III) complex is enhanced especially in the presence of isopropyl alcohol concentration above $1 \mathrm{~mol} \mathrm{dm}^{-3}$. This is because, in addition to catalysis by $\mathrm{Cu}(\mathrm{II}), \alpha$-hydroxy alkyl radical which is formed from alcohol by reacting with $\cdot \mathrm{OH}$, may also react with $\mathrm{Ni}$ (III) and thus responsible for enhanced decomposition of $\mathrm{Ni}(\mathrm{III}) .{ }^{32}$ After the reduction of $\mathrm{Ni}(\mathrm{III})$ to $\mathrm{Ni}(\mathrm{II})$, the suppression of the peak at $520 \mathrm{~nm}$ was observed without affecting the peak at $270 \mathrm{~nm}$. This suggests that the peak produced at $270 \mathrm{~nm}$ is not due to true $\mathrm{Ni}$ (III), but may be a transient species.

Table 4. Effect of isopropyl alcohol on rate constant at $\mathrm{pH}=1:\left[\mathrm{Ni}^{\mathrm{III}} \mathrm{L}_{1}\right]=5 \times 10^{-5} \mathrm{~mol} \mathrm{dm}^{-3} ;\left[\mathrm{H}_{2} \mathrm{O}_{2}\right]=5 \times$ $10^{-4} \mathrm{~mol} \mathrm{dm}^{-3} ; \mathrm{T}=25^{\circ} \mathrm{C} ;[\mathrm{Cu}(\mathrm{II})]=1 \times 10^{-4} \mathrm{~mol} \mathrm{dm}^{-3}$; $\left[\mathrm{Na}_{2} \mathrm{SO}_{4}\right]=0.002 \mathrm{~mol} \mathrm{dm}^{-3} ; \mathrm{I}=0.50 \mathrm{~mol} \mathrm{dm}^{-3}\left(\mathrm{NaClO}_{4}\right)$.

[Isopropyl alcohol] /

\begin{tabular}{lc}
$\mathrm{mol} \mathrm{dm}$ & $\mathrm{k}^{\prime \prime} / \mathrm{dm}^{3} \mathrm{~mol}^{-1} \mathrm{~s}^{-1}$ \\
\hline 1.0 & $17.0 \pm 0.07$ \\
1.5 & $21.5 \pm 0.10$ \\
2.0 & $25.7 \pm 0.05$ \\
2.5 & $28.9 \pm 0.10$ \\
3.0 & $32.5 \pm 0.10$ \\
\hline
\end{tabular}

3.2c Reaction of t-Butyl hydroperoxide with $\mathrm{Ni}(\mathrm{II})$ macrocyclic complexes: Oxidation of $\left[\mathrm{NiL}_{1}\right]\left(\mathrm{ClO}_{4}\right)_{2}$ at $\mathrm{pH} 1$ using excess $t-\mathrm{BuOOH}$ in the presence of sulphate concentration of $0.10 \mathrm{~mol} \mathrm{dm}^{-3}$ displayed ligand to metal charge transfer (LMCT) band at $300 \mathrm{~nm}$ and charge transfer to solvent (CTTS) band at $220 \mathrm{~nm}$ with an isosbestic point at $242 \mathrm{~nm}$. The pseudo-first order rate constant, $\mathrm{k}_{\mathrm{obs}}$, was found to be $2.42 \times 10^{-4} \mathrm{~s}^{-1}$. In the presence of sulphate, the nickel(III) produced in the reaction of $\left[\mathrm{NiL}_{1}\right]^{2+}$ with $t$-BuO was stable. With $\left[\mathrm{NiL}_{2}\right]\left(\mathrm{ClO}_{4}\right)_{2}$, the appearance of an intense band (LMCT) at $290 \mathrm{~nm}$ in the presence of sulphate ion suggests the formation of $\mathrm{Ni}(\mathrm{III})$ at the same reaction

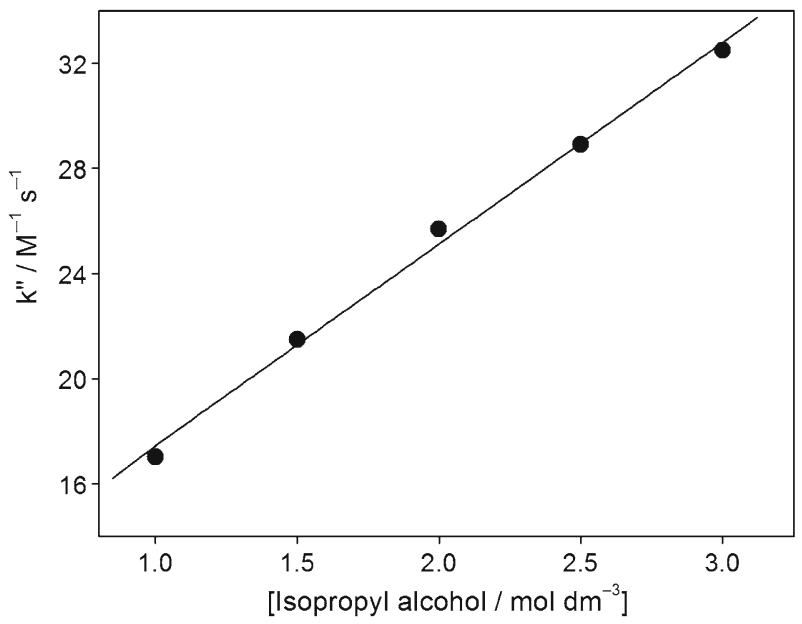

Figure 5. Effect of isopropyl alcohol on rate constant: $\left[\mathrm{Ni}^{\mathrm{III}} \mathrm{L}_{1}\right]=5 \times 10^{-5} \mathrm{~mol} \mathrm{dm^{-3 }} ; \mathrm{pH}=1\left(\mathrm{HClO}_{4}\right)$; $\left[\mathrm{Na}_{2} \mathrm{SO}_{4}\right]=0.002 \mathrm{~mol} \mathrm{dm}^{-3} ; \mathrm{Temp}=25^{\circ} \mathrm{C} ; \mathrm{I}=0.50 \mathrm{~mol}$ $\mathrm{dm}^{-3}\left(\mathrm{NaClO}_{4}\right) ;[\mathrm{Cu}(\mathrm{II})]=1 \times 10^{-4} \mathrm{~mol} \mathrm{dm}^{-3} ;\left[\mathrm{H}_{2} \mathrm{O}_{2}\right]=$ $5 \times 10^{-4} \mathrm{~mol} \mathrm{dm}^{-3}$. 
Table 5. Rate constants for the oxidation of $[\mathrm{NiL}]^{2+}(\mathrm{L}=$ $\mathrm{L}_{1}, \mathrm{~L}_{2}, \mathrm{~L}_{3}$ and $\left.\mathrm{L}_{4}\right]$ by $t$-Butyl hydroperoxide at $25^{\circ} \mathrm{C}$ : $[\mathrm{NiL}]^{2+}=5 \times 10^{-5} \mathrm{~mol} \mathrm{dm}^{-3},\left[\mathrm{Na}_{2} \mathrm{SO}_{4}\right]=0.10 \mathrm{~mol} \mathrm{dm}^{-3}$, $\mathrm{pH}=1\left(\mathrm{HClO}_{4}\right),[t-\mathrm{BuOOH}]=5 \times 10^{-3} \mathrm{~mol} \mathrm{dm}^{-3}, \mathrm{I}=$ $0.50 \mathrm{~mol} \mathrm{dm}^{-3}\left(\mathrm{NaClO}_{4}\right)$.

\begin{tabular}{lc}
\hline Complex & $\mathrm{k}_{\text {obs }} / 10^{-4}, \mathrm{~s}^{-1}$ \\
\hline$\left[\mathrm{NiL}_{1}\right]^{2+}$ & $2.42 \pm 0.04$ \\
{$\left[\mathrm{NiL}_{2}\right]^{2+}$} & $2.18 \pm 0.02$ \\
{$\left[\mathrm{NiL}_{3}\right]^{2+}$} & Very slow \\
{$\left[\mathrm{NiL}_{4}\right]^{2+}$} & No reaction \\
\hline
\end{tabular}

conditions. During the reaction, the other charge transfer band at $210 \mathrm{~nm}$ (CTTS) decreased in intensity with time, showing an isobestic point at $240 \mathrm{~nm}$.

A metal centre oxidation of the $\left[\mathrm{NiL}_{3}\right]\left(\mathrm{ClO}_{4}\right)_{2}$ complex was very slow with $t$-BuOOH with an increase in LMCT band at $409 \mathrm{~nm}$ and $310 \mathrm{~nm}$ and decreases in the CTTS band at $236 \mathrm{~nm}$. $t$ - $\mathrm{BuOOH}$ has no action on $\left[\mathrm{NiL}_{4}\right]\left(\mathrm{ClO}_{4}\right)_{2}$. Therefore, it was concluded that the $t$ - $\mathrm{BuO}$ would not attack the macrocyclic ligand.

On the basis of the reaction of the above complexes with $t$ - $\mathrm{BuOOH}$, it was concluded that for the $\mathrm{Ni}$ (II) complexes of macrocyclic ligands I-III, the metal centred oxidation takes place, the rates being in the order $\mathrm{NiL}_{1}>\mathrm{NiL}_{2}>\mathrm{NiL}_{3}$ (scheme 1, table 5). With $\mathrm{H}_{2} \mathrm{O}_{2}$, ligand oxidation of macrocyclic ring takes place with complexes I and II in which hydrogen atom of secondary nitrogen can be easily abstracted by ${ }^{\circ} \mathrm{OH}$.

From these studies, in the oxidation of $\left[\mathrm{NiL}_{1}\right]\left(\mathrm{ClO}_{4}\right)_{2}$ by $\mathrm{H}_{2} \mathrm{O}_{2}$, in addition to increase in peak at $280 \mathrm{~nm}$, the progress of the peak at $520 \mathrm{~nm}$ suggest the formation of tetraene form of dimer by removal of an $\alpha$-hydrogen. In the case of $\left[\mathrm{NiL}_{2}\right]\left(\mathrm{ClO}_{4}\right)_{2}$, the $\alpha$-position is strained due to the uncoordinated bridge head nitrogen (N1 and N8) with hydroxyethyl substituent so that it forms only dienes.

\subsection{Correlation with Marcus theory}

According to the modified form of Marcus theory, ${ }^{33}$ the rate constant for a cross-reaction $\mathrm{k}_{12}$ is related to the rate constants for the component exchange reactions $\mathrm{k}_{11}$ and $\mathrm{k}_{22}$ and the equilibrium constant for the cross-reaction $\mathrm{K}_{12}$ by

$$
\mathrm{k}_{12}=\left(\mathrm{k}_{11} \mathrm{k}_{22} \mathrm{k}_{12} f_{12}\right)^{1 / 2} \mathrm{~W}_{12},
$$

where

$$
\begin{aligned}
\operatorname{lnf}_{12} & =\frac{\left[\ln \mathrm{K}_{12}+\left(\mathrm{W}_{12}-\mathrm{W}_{21}\right) / \mathrm{RT}\right]^{2}}{4\left[\ln \left(\mathrm{k}_{11} \mathrm{k}_{22} / \mathrm{A}_{11} \mathrm{~A}_{22}\right)+\left(\left(\mathrm{W}_{11}+\mathrm{W}_{22}\right) / \mathrm{RT}\right)\right]} \\
\mathrm{W}_{12} & =\exp \left[-\left(\mathrm{W}_{12}+\mathrm{W}_{21}-\mathrm{W}_{11}-\mathrm{W}_{22}\right) / 2 \mathrm{RT}\right] \\
\mathrm{W}_{\mathrm{ij}} & =\mathrm{e}^{2} \mathrm{z}_{\mathrm{i}} \mathrm{z}_{\mathrm{j}} / \mathrm{D}_{\mathrm{s}} \sigma_{\mathrm{ij}}\left(1+\beta \sigma_{\mathrm{ij}} \mathrm{I}^{1 / 2}\right) \\
\mathrm{A}_{\mathrm{ii}} & =\left[\frac{4 \pi \mathrm{N} \sigma^{2} v b \gamma \mathrm{r}}{1000}\right]_{\mathrm{ii}}
\end{aligned}
$$

In these expressions $\mathrm{W}_{\mathrm{ij}}$ is the work required to bring ions $i$ and $j$ (charges $\mathrm{z}_{i}$ and $\mathrm{z}_{j}$ ) to the separation distance $\sigma_{i j}$ (taken equal to the sum of $\mathrm{a}_{i}$ and $\mathrm{a}_{j}$, the radii of ions $i$ and $j), \beta=\left(8 \pi \mathrm{Ne}^{2} / 1000 \mathrm{D}_{s} k \mathrm{~T}\right)^{1 / 2}$, and $\mathrm{D}_{\mathrm{s}}$ is the dielectric constant of the medium, $v b$ is the nuclear

Table 6. Cross-reaction and self-exchange rate constants for reactions involving the $\mathrm{HO}_{2}^{-} / \mathrm{HO}_{2}$ couple; ionic strength in parentheses. ${ }^{13,26}$

\begin{tabular}{lcccc}
\hline S. No. & Oxidant $^{\mathrm{a}}$ & $\mathrm{E}^{\circ}(\mathrm{V})$ & $\mathrm{k}_{22}\left(\mathrm{M}^{-1} \mathrm{~s}^{-1}\right)^{\mathrm{b}}$ & $\mathrm{k}_{2}\left(\mathrm{M}^{-1} \mathrm{~s}^{-1}\right)$ \\
\hline I & Os(dmbpy) $)_{3}^{3+}$ & 0.66 & $4.2 \times 10^{8}(0.1)^{\mathrm{c}}$ & $1.00 \times 10^{3}(0.5)$ \\
II & Os(bpy $)_{3}^{3+}$ & 0.81 & $4.2 \times 10^{8}(0.1)^{\mathrm{c}}$ & $6.00 \times 10^{3}(0.5)$ \\
III & $\mathrm{Fe}(\mathrm{dmbpy})_{3}^{3+}$ & 0.81 & $3.0 \times 10^{8}(5.5)$ & $2.70 \times 10^{4}(0.5)$ \\
IV & $\mathrm{Fe}(\mathrm{bpy})_{3}^{3+}$ & 1.05 & $3.0 \times 10^{8}(5.5)$ & $7.10 \times 10^{5}(0.5)$ \\
V & $\mathrm{Ru}(\mathrm{dmbpy})_{3}^{3+}$ & 1.06 & $4.2 \times 10^{8}(0.1)$ & $1.30 \times 10^{6}(0.5)$ \\
VI & $\mathrm{Ru}(\mathrm{bpy})_{3}^{3+}$ & 1.26 & $4.2 \times 10^{8}(0.1)$ & $2.40 \times 10^{7}(0.5)$ \\
VI & $\mathrm{Ni}(\mathrm{dmbpy})_{3}^{3+}$ & 1.59 & $1.5 \times 10^{3}(1.0)$ & $3.30 \times 10^{7}(0.5)$ \\
VIII & $\mathrm{Ni}(\mathrm{bpy})_{3}^{3+}$ & 1.72 & $1.5 \times 10^{3}(1.0)$ & $2.40 \times 10^{8}(0.5)$ \\
IX & $\mathrm{Fe}(\mathrm{ttcn})_{2}^{3+}$ & 1.44 & $6.7 \times 10^{6}(0.5)$ & $2.63 \times 10^{9}(0.1)$ \\
X & $\mathrm{Ni}(\mathrm{tacn})_{2}^{3+}$ & 0.95 & $6.0 \times 10^{3}(1.0)$ & $6.15 \times 10^{6}(0.1)$ \\
XI & $\mathrm{Ni}^{\mathrm{III}} \mathrm{L}_{1}$ & 0.97 & $2.0 \times 10^{3}(1.0)$ & $1.79 \times 10^{11}(0.5)^{* *}$ \\
\hline
\end{tabular}

${ }^{\mathrm{a}} \mathrm{dmbpy}=4,4^{\prime}-\left(\mathrm{CH}_{3}\right)_{2}$ bpy; py $=$ pyridine; tacn $=(1,4,7$-triazacyclononane $) ;$ ttcn $=(1,4,7-$ trithiacyclononane)

${ }^{b}$ Self-exchange rate constants: $\mathrm{k}_{22}$ is for partner of $\mathrm{HO}_{2}^{-}$or $\mathrm{HO}_{2}$ in cross-reaction

${ }^{\mathrm{c}} \mathrm{k}_{22}$ for $\mathrm{OsL}_{3}^{2+/ 3+}$ is assumed to be the same as for $\mathrm{Ru}(\mathrm{bpy})_{3}^{2+/ 3+}$

$\mathrm{k}_{2}=$ rate constant for cross reaction; $* *$ - present work in the absence of $[\mathrm{Cu}(\mathrm{II})]$ and $\left[\mathrm{SO}_{4}^{2-}\right]$ 


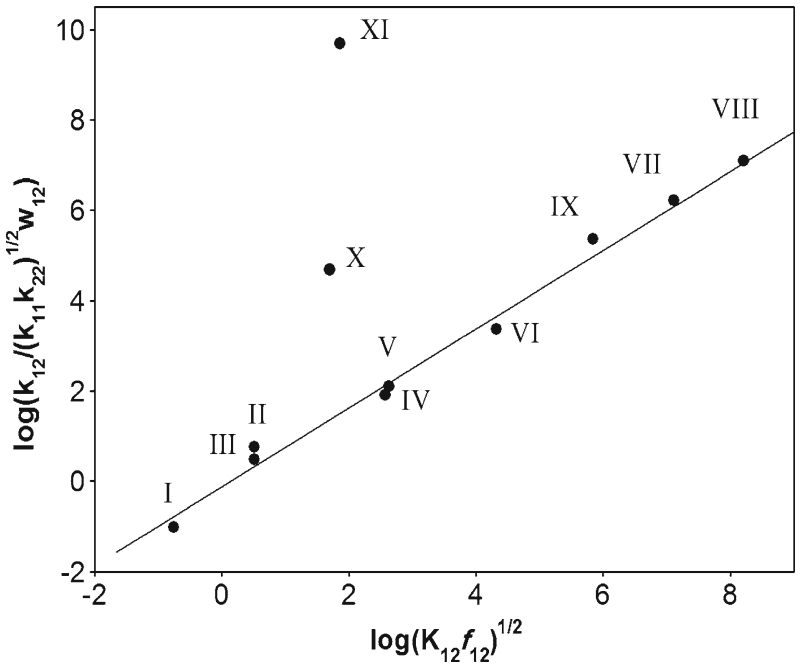

Figure 6. Plot of $\left.\log \mathrm{k}_{12} /\left(\mathrm{k}_{11} \mathrm{k}_{22}\right)^{1 / 2} W_{12}\right)$ vs. $\ln \left[\left(\mathrm{K}_{12} f_{12}\right)^{1 / 2}\right]$; The Roman numbers denote that each circle represents the reaction of $\mathrm{HO}_{2}^{-}$with: Os(dmbpy $)_{3}^{3+}, \mathrm{I}$; Os(bpy $)_{3}^{3+}$, II; $\mathrm{Fe}(\mathrm{dmbpy})_{3}^{3+}$, III; $\mathrm{Fe}(\mathrm{bpy})_{3}^{3+}$, IV: $\mathrm{Ru}(\mathrm{dmbpy})_{3}^{3+}, \mathrm{V}$; $\mathrm{Ru}(\mathrm{bpy})_{3}^{3+}$, VI; Ni(dmbpy $)_{3}^{3+}$, VII; Ni(bpy) ${ }_{3}^{3+}$, VIII; $\left.\mathrm{Fe}(\mathrm{ttcn})_{2}\right]^{3+}, \mathrm{IX} ; \mathrm{Ni}(\operatorname{tacn})_{2}^{3+}, \mathrm{X} ; \mathrm{Ni}^{\mathrm{III}} \mathrm{L}_{1}, \mathrm{XI}$. The points are calculated using $\mathrm{k}_{11}$ for $\mathrm{HO}_{2}^{-} / \mathrm{HO}_{2}=5 \times 10^{-2} \mathrm{M}^{-1} \mathrm{~s}^{-1}$.

frequency that destroys the activated complex configuration $\left(\sim 9 \times 10^{12} \mathrm{~s}^{-1}\right)$, and $\gamma \mathrm{r}$ is the thickness of the reaction layer (typically $\sim 0.8 \AA$ ). Value of $\mathrm{A} / \sigma^{2}$ for the $\mathrm{Ni}(\mathrm{III})$ complex has been taken as $4.8 \times 10^{10} \mathrm{M}^{-1} \AA^{-2}$ $\mathrm{s}^{-1}$ and the value of $\mathrm{A}_{11} \mathrm{~A}_{22}$ for the $\mathrm{ML}_{3}^{3+} / \mathrm{HO}_{2}^{-}$reactions is taken as $2 \times 10^{24} \mathrm{M}^{-2} \mathrm{~s}^{-2}$. The radii of the $\left[\mathrm{NiL}_{1}\right]^{3+}$ and the peroxide anion are $5.0 \AA$ and $1.6 \AA$, respectively. ${ }^{12,34}$

The redox potential of $\mathrm{HO}_{2}$ is taken as $0.75 \mathrm{~V}^{28}$ With $\mathrm{k}_{11}=5 \times 10^{-2} \mathrm{M}^{-1} \mathrm{~s}^{-1}$, the plot of $\log$ $\left(\mathrm{k}_{12} /\left(\mathrm{k}_{11} \mathrm{k}_{22}\right)^{1 / 2} \mathrm{~W}_{12}\right)$ against $\log \left(\mathrm{K}_{12} \mathrm{f}_{12}\right)^{1 / 2}$ indicates that the rate constants $\mathrm{k}_{2}$ for the oxidation of $\mathrm{HO}_{2}^{-}$ increase as the reduction potentials of the oxidants in the series is increased except of $\left[\mathrm{Ni}(\operatorname{tacn})_{2}\right]^{3+}$ and $\left[\mathrm{NiL}_{1}\right]^{3+}$ complexes (table 6 and figure 6). Similar to $\left[\mathrm{Ni}(\operatorname{tacn})_{2}\right]^{3+}$, interaction of $\left[\mathrm{Ni}^{\mathrm{III}} \mathrm{L}_{1}\right]$ with $\mathrm{HO}_{2}^{-}$is represented by the following scheme $4 .{ }^{13}$

The rate constant for the oxidation of $\mathrm{HO}_{2}^{-}$by $\left[\mathrm{Ni}^{\mathrm{III}} \mathrm{L}_{1}\right]$ is greater than that predicted by outer sphere reactions.

\subsection{Estimation of hydrogen peroxide}

An attempt has been made to estimate the amount of hydrogen peroxide remaining in the solution after oxidation of hydrogen peroxide by $\left[\mathrm{Ni}^{\mathrm{III}} \mathrm{L}_{1}\right]$ complex. ${ }^{35,36}$

A reagent solution containing xylenol orange $(\mathrm{XO})$ $\left(5 \times 10^{-4} \mathrm{~mol} \mathrm{dm}^{-3}\right)$ and $\mathrm{Fe}(\mathrm{II})$ ammonium sulphate $\left(2 \times 10^{-4} \mathrm{~mol} \mathrm{dm}^{-3}\right)$ was prepared in perchloric acid medium. The resultant $\mathrm{pH}$ of the solution was adjusted to $\mathrm{pH} 1.8$. The $\mathrm{H}_{2} \mathrm{O}_{2}\left(5 \times 10^{-5} \mathrm{~mol} \mathrm{dm}^{-3}\right)$ was added to the solution and the volume of the solution was made up to $5 \mathrm{ml}$. The absorbance was measured at $550 \mathrm{~nm}$ against blank. The concentration of the $\mathrm{H}_{2} \mathrm{O}_{2}$ was calculated using the extinction coefficient $2.68 \times$ $10^{4} \mathrm{M}^{-1} \mathrm{~cm}^{-1}$.

Oxidation of $\mathrm{H}_{2} \mathrm{O}_{2}$ by $\left[\mathrm{Ni}^{\mathrm{III}} \mathrm{L}_{1}\right]$ at $\mathrm{pH} 1.5$ was studied in the absence of sulphate with $[\mathrm{Cu}(\mathrm{II})]$ of $1 \times 10^{-4} \mathrm{~mol}$ $\mathrm{dm}^{-3}$. The ratio of $\mathrm{Ni}(\mathrm{III}): \mathrm{H}_{2} \mathrm{O}_{2}$ was $1: 5$. As soon as the absorbance $\lambda_{\max }$ due to Ni(III) disappear $1 \mathrm{ml}$ of the reaction mixture was pipetted out immediately and was added to the reagent mixture containing xylenol orange of the resulting $\mathrm{pH} 1.8\left(\mathrm{HClO}_{4}\right)$. Then the absorbance was measured against blank. The concentration of the resultant $\mathrm{H}_{2} \mathrm{O}_{2}$ was found to be $4.3 \times 10^{-5} \mathrm{~mol} \mathrm{dm}^{-3}$. This result suggests a stoichiometry of 2:1 for the reaction. The slight decrease in resultant concentration may be an error or may due to the reaction of $' \mathrm{OH}$ radical by the $\mathrm{Ni}$ (II) formed as product of reduction of $\mathrm{Ni}(\mathrm{III})$.

Thus, the copper catalysed oxidation of hydrogen peroxide by $\left[\mathrm{Ni}^{\mathrm{III}} \mathrm{L}_{1}\right]$ reaction is mainly due to the $\mathrm{HO}_{2}^{-}$ ion rather than the reaction of ${ }^{\circ} \mathrm{OH}$ radical.

\section{Conclusions}

In summery, the kinetics of oxidation of hydrogen peroxide by $[\mathrm{Ni}(\text { cyclam })]^{3+}$ shows that the reaction is catalysed by the presence of $\mathrm{Cu}$ (II) ion in acidic aqueous solution and is faster in the presence of $\mathrm{Cu}$ (II) ion than in its absence. The reduction of the metal centre is faster than the cyclam ligand oxidation to form tetraene by peroxide ion.

\section{Acknowledgement}

Authors are grateful to Prof. J Subramanian, Central Leather Research Institute, Chennai, for EPR measurements.

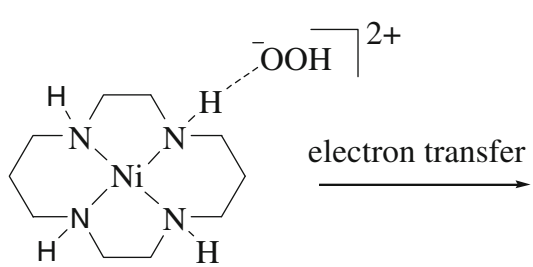

Scheme 4. Mode of electron transfer between $\left[\mathrm{Ni}^{\mathrm{III}} \mathrm{L}_{1}\right]$ and peroxy anion. 


\section{References}

1. Evans M G, George P and Uri N 1949 Trans. Faraday Soc. 45230

2. Jones P, Kitching R, Tobe M L and Wynne Jones W F K 1959 Trans. Faraday Soc. $\mathbf{5 5} 79$

3. Kremer M L and Stein G 1959 Trans. Faraday Soc. 55 959

4. Wells C F and Fox D 1976 J. Inorg. Nucl. Chem. 38 107

5. Wells C F and Husain M 1970 J. Chem. Soc. (A) 1013

6. Wells C F and Mays D 1968 J. Chem. Soc. (A) 665

7. Baxendale J H and Wells C F 1957 Trans. Faraday Soc. 53800

8. Wells C F and Husain M 1971 Trans. Faraday Soc. 67 760

9. Wells C F and Mays D 1969 Inorg. Nucl. Chem. Lett. 59

10. Sharma V K, Millero F J and Homonnay Z 2004 Inorg. Chim. Acta 3573583

11. Wells C F and Fox D 1977 J. Chem. Soc. Dalton Trans. 1498

12. Macartney D H 1986 Can. J. Chem. 641936

13. Koshino N, Funahashi S and Takagi H D 1997 J. Chem. Soc. Dalton Trans. 4175

14. McAuley A and Xu C 1992 Inorg. Chem. 315549

15. Whitburn K D and Laurence G S, 1979 J Chem. Soc. Dalton Trans. 139

16. Xavier Solans-Monfort, Jose Lis G Fierro, Lara Hermosilla, Carlos Sieiro, Mariona Sodpe and Ruben Mas-Balleste 2011 Dalton Trans. 406868

17. Barefield E K, Wagner F, Herlinger A W and Dahl A R 1976 Inorg. Synth. 16222

18. McAuley A, Palmer T A and Whitcombe T W 1993 Can. J. Chem. 711792
19. Suh M P, Shim B Y and Yoon T 1994 Inorg. Chem. 33 5509

20. Tait A M and Busch D H 1972 Inorg. Nucl. Chem. Lett. 8491

21. Cohen H, Krischenbaum L J, Zeigerson E, Jaacobi M, Fuchs E, Ginsbrg G and Meyerstein D 1979 Inorg. Chem. 182763

22. Jaacobi M, Meyerstein D and Lilie J 1979 Inorg. Chem. 18429

23. Espenson J H 1995 Chemical kinetics and reaction mechanisms, 2nd edition, McGraw-Hill

24. Meshulam A, Cohen H and Meyerstein D 1998 Inorg. Chim. Acta 273266

25. Ariela Brg, Eric Maimon, Haim Cohen and Dan Meyerstein 2007 Eur. J. Inorg. Chem. 530

26. Cheves Walling and Andre Goosen 1973 J. Am. Chem. Soc. 952987

27. Haber F and Weiss J 1934 J. Proc. R. Soc. (London) A147 332

28. Barb W G, Baxendale J H, George P and Harorave K R 1951 Trans Faraday Soc. 47591

29. Mordechai L Kremer 1962 J. Catal. 1351

30. Pecci L, Montefoschi G and Cavallini D 1997 Biochem. Biophy. Res. Commun. 235264

31. Rabani J, Klug-Roth D, Lilie J 1973 J. Phy. Chem. 77 1169

32. Yao Q, Bakac A, Espenson J H 1993 Inorg. Chem. 32 1488

33. Sutin N 1982 Acc. Chem. Res. 15 275; 1983 Prog. Inorg. Chem. 30441

34. Macartney D H and Sutin N 1983 Inorg. Chim. Acta 74 221

35. Gupta B L 1973 J. Microchem. 18363

36. Gay C, Collins J and Gebicki J M 1999 Anal. Biochem. 273149 